\title{
QUATERNARY PROBOSCIDEAN (MAMMALIA) REMAINS OF THE UIS GEOLOGICAL MUSEUM, COLOMBIA
}

\author{
JAIME YESID SUÁREZ-IBARRA (D \\ Programa de Pós-Graduação em Geociências, Instituto de Geociências, Universidade Federal do Rio Grande do Sul, \\ Av. Bento Gonçalves, 9500, Cx.P. 15001, 91501-970, Porto Alegre, RS, Brazil. \\ jaime_yesid16@hotmail.com \\ GINA CARDOSO ID \\ Escola de Ensino Fundamental Oiticicas, Rua do Bem, Oiticicas, Zona Rural, 62300-000, Viçosa do Ceará, CE, Brazil. \\ gina.caroly@hotmail.com \\ LIDIANE ASEVEDO (1), LUCAS DE MELO FRANÇA (1) \\ Programa de Pós-Graduação em Ecologia e Conservação, Universidade Federal de Sergipe, \\ Av. Marechal Rondon s/n, 49100-000, Jardim Rosa Elze, São Cristóvão, Sergipe, Brazil. \\ lidi.asevedo@gmail.com,lucasmfranca@hotmail.com \\ MÁRIO ANDRE TRINDADE DANTAS (1) \\ Laboratório de Ecologia e Geociências, Universidade Federal da Bahia (IMS/CAT), \\ Rua Hormindo Barros, 58, Candeias, 45029-094, Vitória da Conquista, BA, Brazil. \\ matdantas@yahoo.com.br \\ LUIS ENRIQUE CRUZ-GUEVARA (1), ANDRÉS FELIPE ROJAS-MANTILLA (1) \\ Escuela de Geología, Universidad Industrial de Santander, Carrera 27 con calle 9, \\ Ciudad Universitaria, Bucaramanga, Santander, Colombia. \\ lecruz@uis.edu.co, andreshrojas97@gmail.com \\ ANA MARIA RIBEIRO (1) \\ Museu de Ciências Naturais/SEMA, Rua Dr. Salvador França, 1427, 90.690-000, Porto Alegre, RS, Brazil. \\ ana-ribeiro@sema.rs.gov.br
}

\begin{abstract}
Proboscideans arrived in South America from North America during the Great American Biotic Interchange, becoming one of the most representative animals of the megafauna that inhabited this continent throughout the Quaternary. In Colombia, the abundance of their remains contrasts with scarce scientific descriptions and publications. This paper identifies dental and postcranial proboscidean fossils from the Center and Northeast of Colombia. The fossil remains were identified as molars (six), a tusk, cervical vertebrae, and a distal part of the right humerus. The tusk was assigned to Notiomastodon platensis, while the other remains were assigned to Gomphotheriidae, with at least six individuals: two immatures, two subadults, and two older adults - mature and senile.
\end{abstract}

Keywords: South America, megamammals, taxonomy, Gomphotheriidae, Notiomastodon platensis.

\section{INTRODUCTION}

The Great American Biotic Interchange (GABI) was an important biogeographic event characterized by a series of land mammal migration episodes from North to South America and vice-versa. Proboscideans and other lineages of megamammals (e.g. Perissodactyla, Cetartiodactyla, and Carnivora) migrated to South America after the Panama Isthmus uplift, during late Pliocene-Pleistocene (Woodburne, 2010). New taxonomic/systematic studies of the South American proboscideans restricted them to only two species from distinct genera: Cuvieronius hyodon Fischer, 1814 and Notiomastodon platensis Ameghino, 1888 (Mothé et al., 
2012). This revision was based on detailed comparative studies of cranium, teeth and postcranial fossil remains from South America, and allowed the taxonomic re-assignation of Stegomastodon Pohlig, 1912 and Haplomastodon Hoffstetter, 1950 to Notiomastodon (Mothé et al., 2012).

Another extensive revision of South American proboscideans was made by Mothé \& Avilla (2015), which argued that a great part of the proboscidean fossil remains in South America is not diagnostic at the specific level. Nevertheless, regarding the diagnostic specimens, it was noted that both species were present in lowland and highland localities, disagreeing with previous traditional inferences about a distinct dispersion process that could have influenced their paleobiogeography history (e.g. Prado et al., 2005). Furthermore, the study of Mothé \& Avilla (2015) also stated that the Peruvian proboscidean Amahuacatherium peruvium Romero-Pittman, 1996 is not a valid taxon and might be a synonym of Notiomastodon platensis.

Posteriorly, the analysis of cranial and postcranial diagnostic elements of immature and adult specimens from North and South America made by Mothé et al. (2017a, b) revealed that Stegomastodon was not present in South America, being restricted only to North America, in agreement with the proposal of Ferretti (2008, 2010), Mothé et al. (2012) and Lucas (2013). This reinforces Cuvieronius hyodon and Notiomastodon platensis as the only proboscidean species recognized for South America Quaternary.

Proboscidean fossils have been recorded in almost all South American countries, being one of the most common megafauna elements in the fossiliferous outcrops (PaulaCouto, 1979; Ferretti, 2008). In Colombia, their records are abundant but rarely scientifically studied and published (Páramo \& Escobar, 2010; Mothé et al., 2017a).

Although only Notiomastodon platensis and other nondiagnostic proboscidean remains are reported for Colombia so far (Mothé \& Avilla, 2015), their taxonomic determinations shall be carefully performed, since Cuvieronius hyodon is found in North, Central and South America, and Colombia is the only viable entrance path for this species. Thus, this paper aims to (i) identify the dental and postcranial fossil remains from the Center and Northeast of Colombia housed in the Geological Museum of the Universidad Industrial de Santander (UIS), and (ii) estimate the number of individuals and their age classes.

\section{MATERIAL AND METHODS}

Six molars, a fragmented tusk, a cervical vertebra and a distal part of the right humerus constitute the identified material. Part of the material (FX-800, FX-801) corresponds to the founding mentioned by Porta (1965) for Curití (Santander), and other remains (FX-838, FX-841) are from Mosquera (Cundinamarca). Other pieces (FX-843, FX-844, FX-893, FX-850, FX-851) have no specific location but are associated to these two localities (Figure 1). Currently, the whole sample is housed at the Geological Museum "Marino Arce Herrera" UIS, Bucaramanga, Colombia.
The taxonomic identification of the fossils followed Osborn (1936, 1942), Simpson \& Paula Couto (1957), Paula-Couto (1979), Ferretti (2010) and Mothé et al. (2012). The description and measurements of the tooth specimens were based on the nomenclature of Tassy (1996) and the postcranial elements of Ferretti (2010).

For age class inferences, we followed the age estimation established for Notiomastodon platensis by Mothé et al. (2010), which is based on the method of classifying extant elephant ages. Thus, the authors related the $N$. platensis tooth classification and its wear stages (Simpson \& Paula Couto, 1957; Table 1) to the age intervals of each tooth usage by the extant elephants (Moss, 1996; Table 1). Posteriorly, the presupposed ages were categorized in classes according to modern elephant populations proposed by Haynes (1991), which includes immature (0-12 years old), subadult (13-24 years), adult (25-36 years), mature adult (37-48 years) and senile adult (49-60 years).

The counting of individuals was based on the minimum number of individuals index (MNI), using the most abundant skeletal element from either the left or right side of the animal (Lyman, 1994), as well as considering the age and wear stages classifications.

\section{SYSTEMATIC PALEONTOLOGY}

\author{
PROBOSCIDEA Illiger, 1811 \\ ELEPHANTOIDEA Gray, 1821 \\ GOMPHOTHERIIDAE Hay, 1922
}

(Figures 2A-I)

Material. FX-800, right lower second molar (Figure 2A); FX-838, right lower third molar (Figure 2B); FX-841, right upper third molar (Figure 2C); FX-801, right upper fourth deciduous molar (Figure 2D); FX-850, fourth deciduous molar fragment (Figure 2E); FX-851, first molar fragment (Figure 2F); FX-843, cervical vertebrae fragment (Figure 2G-H); FX-844, right humerus fragment (Figure 2I).

Description. FX-800 is a trilophodont right $M_{2}$ with superficial wear in anterior lophids (wear stage 1), and the trefoil pattern is not evident (Figure 2A). The specimen is fragmented in the mesoconelet cusp, close to the main pretrite cusp, hypoconid, from second lophid (metalophid), and also, in the region of the main posttrite cusp, postentoconulid from third lophid (tritolophid; Figure 2A). The fragmentation probably was produced during-after the excavation. This molar belongs to a subadult individual, with an age around 19 to 24 years old (Table 2). FX-838 is a right pentalophodont $\mathrm{M}_{3}$ with the first lophid (protolophid) absent. The anterior lophids of the metalophid and tritolophid are more worn (wear stage 2), showing simple trefoil pattern and several accessory conelets (Figure 2B). The specimen can be assigned to a mature adult individual between 41 to 47 years old (Table 2). FX-841 is a right pentalophodont $\mathrm{M}^{3}$ specimen without the first loph (protoloph), and advanced wear stage 4 . The metaloph and tritoloph are completely obliterated exposing great part of the dentin (Figure 2C). No trefoil pattern is recognizable 


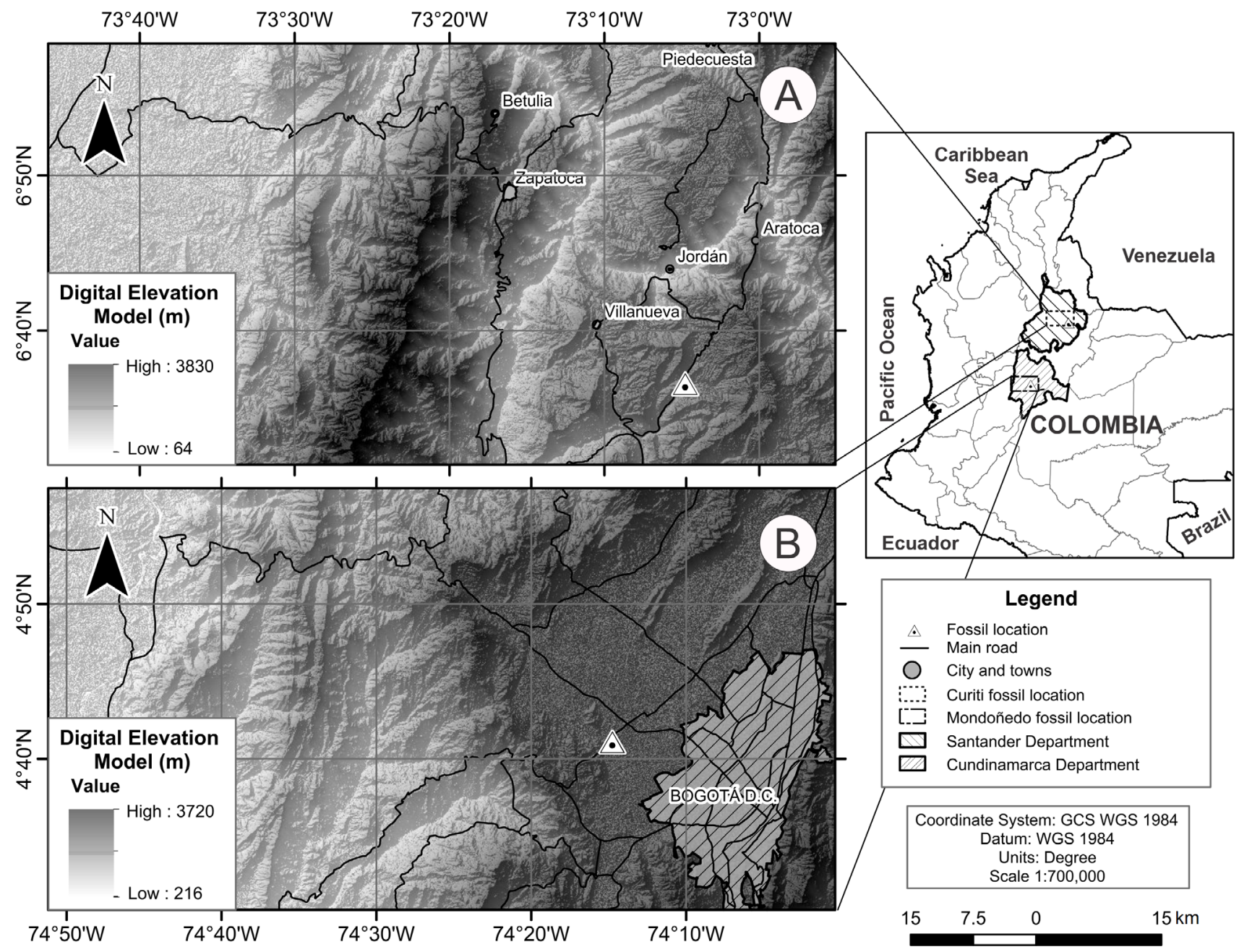

Figure 1. Map showing the localities with gomphotheres remains, marked by white triangles with black points, for Curití, Santander (A) and Mondoñedo (Mosquera), Cundinamarca (B), Colombia.

Table 1. Teeth usage intervals (in years) for extant elephants by Moss (1996), and wear stages proposed by Simpson \& Paula Couto (1957).

\begin{tabular}{cccc}
\hline \multirow{2}{*}{ Tooth } & \multicolumn{2}{c}{ Teeth usage intervals } & Wear stages \\
\cline { 2 - 3 } & eruption $(\mathrm{yr})$ & lost $(\mathrm{yr})$ & 0 Tooth formed but not erupted \\
$\mathrm{DP}^{2} / \mathrm{DP}_{2}$ & 0 & 1 & $0+=$ Tooth erupted but not worn \\
$\mathrm{DP}^{3} / \mathrm{DP}_{3}$ & 0.6 & 7 & $1=$ Wear present only in anterior lophids \\
$\mathrm{DP}^{4} / \mathrm{DP}_{4}$ & 1 & 22 & $2=$ Light wear in all lophids \\
$\mathrm{M}^{1} / \mathrm{M}_{1}$ & 10 & 40 & $3=$ Great wear with lophids still visible \\
$\mathrm{M}^{2} / \mathrm{M}_{2}$ & 14 & 60 & 4 = Severe wear with lophids partially or totally obliterated \\
$\mathrm{M}^{3} / \mathrm{M}_{3}$ & 28 & &
\end{tabular}

Table 2. Summary of molar specimens' characteristics, measurements ( $\mathrm{mm}$ ) and age classes estimated. Abbreviations: G, L, greatest length; W, L, width loph/id; NL, number of loph/ids; WS, wear stage; $\mathbf{A C}$, age class (years).

\begin{tabular}{|c|c|c|c|c|c|c|c|c|c|c|}
\hline Tooth & $\mathrm{N}^{\circ}$ & GL & $\mathrm{W} 1^{\circ} \mathrm{L}$ & $\mathrm{W} 2{ }^{\circ} \mathrm{L}$ & $\mathrm{W} 3^{\circ} \mathrm{L}$ & $\mathrm{W} 4^{\circ} \mathrm{L}$ & $\mathrm{W} 5^{\circ} \mathrm{L}$ & NL & WS & $\mathrm{AC}$ \\
\hline Right DP 4 & FX-801 & 71 & 46 & 44 & 37 & - & - & 3 & 2 & Immature (3-5) \\
\hline Right $\mathrm{M}_{2}$ & FX-800 & 137 & 65 & 61 & 58 & - & - & 3 & 1 & Subadult (19-24) \\
\hline Right $\mathrm{M}_{3}$ & FX-838 & 152 & - & 74 & 58 & 45 & 34 & $5 ?$ & 2 & Mature adult (41-47) \\
\hline Right $\mathrm{M}^{3}$ & FX-841 & 165 & - & 68 & 67 & 65 & 42 & $5 ?$ & 4 & Senile adult $(\geq 53)$ \\
\hline $\mathrm{DP}^{4}$ or $\mathrm{DP}_{4}$ & FX-850 & - & - & - & - & - & - & $?$ & $2 ?$ & Immature (3-5) \\
\hline $\mathrm{M}^{1}$ or $\mathrm{M}_{1}^{4}$ & FX-851 & - & - & - & - & - & - & $?$ & $3 ?$ & Subadult (17.5-20) \\
\hline
\end{tabular}



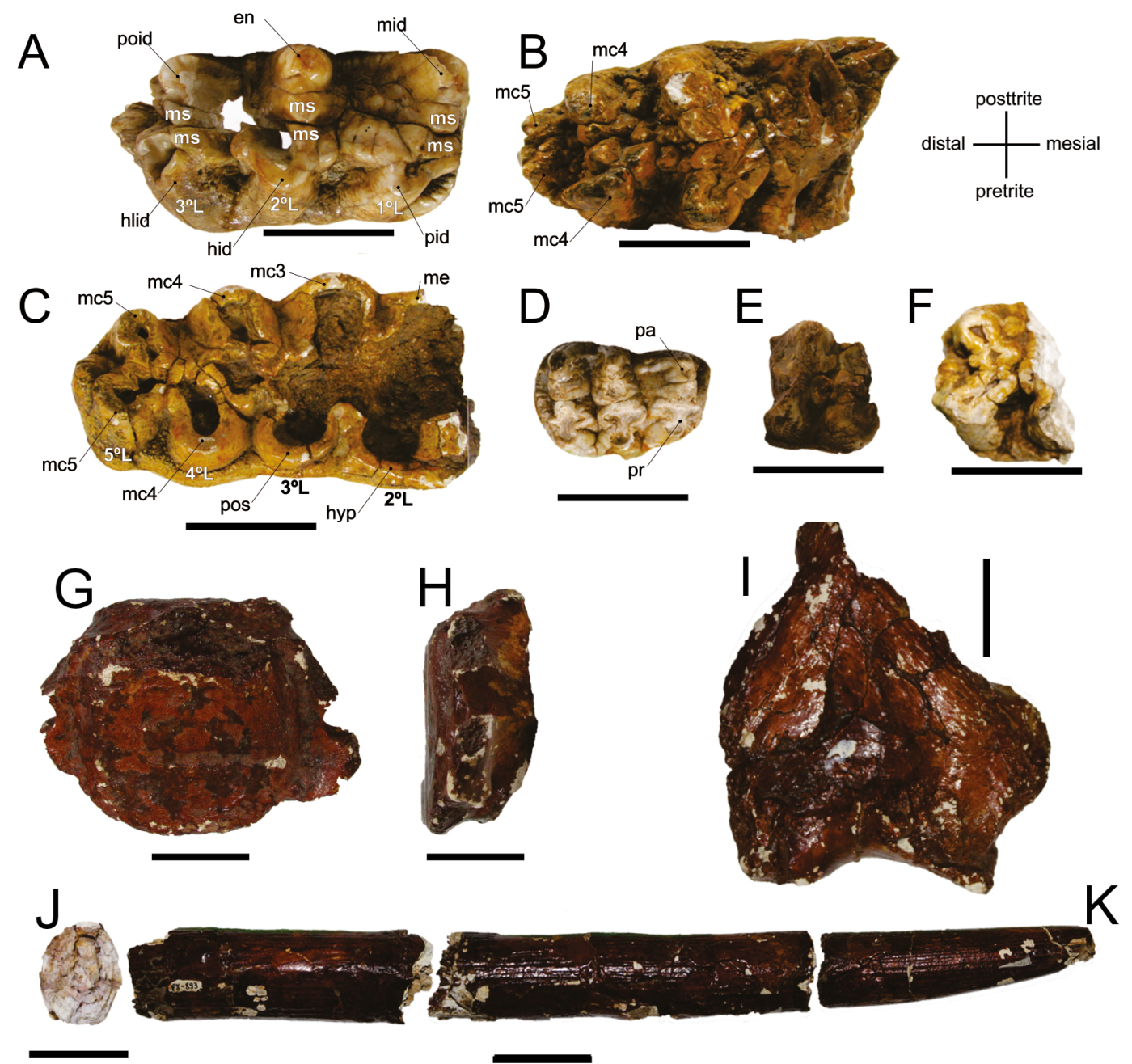

Figure 2. A-F, molar specimens (in occlusal view) of Gomphotheriidae. A, right $\mathrm{M}_{2}$ (FX-800); B, right $\mathrm{M}_{3}$ (FX-838); C, right $\mathrm{M}^{3}$ (FX-841); D, right DP ${ }^{4}$ (FX-801); E, lower or upper DP4 (FX-850); F, lower or upper M1 (FX-851). G-H, cervical vertebra body fragment (FX-843) of Gomphotheriidae, G, anterior view; H, lateral view. I, right humerus distal portion (FX-844) of Gomphotheriidae in posterior view. J-K, upper tusk of Notiomastodon platensis (FX-893), $\mathbf{J}$, transversal view; K, lateral view. Abbreviations: Pair of cusps from upper (loph) and lower (lophid) tooth: protoloph/id $\left(\mathbf{1}^{\circ} \mathbf{L}\right), \mathrm{metaloph} / \mathrm{id}\left(\mathbf{2}^{\circ} \mathbf{L}\right)$, tritoloph/ id $\left(3^{\circ} \mathbf{L}\right)$, fourth and fifth loph/lophid $\left(4^{\circ} \mathbf{L}-5^{\circ} \mathbf{L}\right), \mathbf{m s}$, mesoconelet. Lower molars (A and B), pretrite: pid, protoconid, hid, hypoconid, hlid, hypoconulid, mc4-mc5, main pretrite cusp of the fourth and fifth lophid; posttrite: mid, metaconid, en, entoconid, poid, postentoconulid, mc4-me5, main posttrite cusp of the fourth and fifth lophid. Upper molars (C and D), pretrite: pr, protocone, hyp, hypocone, pos, postentoconule, mc4-mc5, main posttrite cusp of the fourth and fifth loph; posttrite: pa, paracone, me, metacone, mc3-mc5, main posttrite cusp of the third to fifth loph. Scale bars $=50 \mathrm{~mm}$.

for this specimen. It could belong to a senile adult; whose age probably was over 53 years old (Table 2). FX-801 is a trilophodont right $\mathrm{DP}^{4}$ specimen with all cusps worn (wear stage 2), showing a simple trefoil pattern (Figure 2D). It could be associated to an immature individual with an age approximately between three to five years old (Table 2). FX-850 is a fragment of lower or upper DP4, with two loph/ lophids preserved, metaloph/id and protoloph/id or tritoloph/ id (Figure 2E). The cusps are slightly worn out (wear stage 2). The specimen was recognized as an immature individual with an age between three to five years old (Table 2). FX851 is a fragment of lower or upper M1, with small part of metaloph/id and tritoloph/id, with the cusps obliterated (wear stage 3?; Figure 2F). It possibly could be associated to subadult individual with 17 to 20 years old (Table 2). FX-843 is a cervical vertebrae fragment without neural spine (Figures $2 \mathrm{G}-\mathrm{H}$ ). Width of cranial articular surface:
$153 \mathrm{~mm}$ and greatest length of corpus: $41 \mathrm{~mm}$. FX-844 is a right humerus distal fragment (Figure 2I). Width of distal articular surface: $122 \mathrm{~mm}$.

PROBOSCIDEA Illiger, 1811

ELEPHANTOIDEA Gray, 1821

GOMPHOTHERIIDAE Hay, 1922

Notiomastodon platensis (Ameghino, 1888)

(Figures 2J-K)

Material. FX-893, upper tusk fragment (Figures 2J-K).

Description. FX-893 is an upper tusk fragment which shows well-preserved internal layered structure, oval cross section (Figure 2J), straight axis and parallel superficial channels all along the tusk (Figure 2K). Tusk measurements are $620 \mathrm{~mm}$ length and maximum diameter of $51 \mathrm{~mm}$. 


\section{DISCUSSION}

The stratigraphic characteristics of Mondoñedo (Mosquera) fossil outcrops are extensively described by Porta (1961a), as well as its taphonomical attributes (i.e. fossil-sediment relation, fragmentation; fig. 6 of Porta, 1961a). Mondoñedo outcrops usually lacked small pieces, had fragmented long bones and showed a low species-diversity but a high number of individual remains (Porta, 1961a, b). In this sense, the elements FX-838 and FX-841, which belong to adult forms, agree with Porta's (1961a, b) descriptions. On the other hand, the Curiti fossil remains were found in recent cracks of the Cretaceous Rosablanca (Formation) limestones (Porta, 1965). These limestones were part of a quarry that used dynamite for rock exploration and, due to the explosions, most of the material suffered anthropogenic fragmentation, as can be evidenced in the $3^{\text {rd }}$ lophid of the right $\mathrm{M}_{2}$ element FX-800. The report of the right $\mathrm{DP}^{4}(\mathrm{FX}-801)$ molar increases the South American immature proboscidean record, which in most cases are compounded by adult individual remains (Andrade et al., 2020).

Most studies for Colombia, even the recent ones (e.g. Villarroel et al., 1996; Villarroel \& Clavijo, 2005; RodriguezFlorez et al., 2009; Páramo \& Escobar, 2010; PardoJaramillo, 2012; this study), are limited to anatomic features identification, and only very few deal with chronologic issues (e.g. ${ }^{14} \mathrm{C}$ age of an unidentified fossil bone, CorrealUrego, 1982); furthermore, in the review made by Mothé et al. (2017a), from 90 items cited, no single specimen had a specific associated age.

The anatomical analysis of the upper tusk (FX-893) led to the recognition of a straight axis format and an oval cross section, which is part of the diagnostic characteristics for Notiomastodon platensis (Mothé et al., 2012; Mothé \& Avilla, 2015). But, since the tusk does not have a specified location, the association of species level with other postcranial and dental remains is not possible.

The age estimates of the gomphothere individuals in the assemblages indicate for Curití an immature and a subadult individual and, for Mosquera a mature adult and a senile adult individual. According to the MNI index results, the remains are composed by at least six individuals, two immatures (FX801, $\mathrm{DP}_{4}$ and FX-850, DP4), two subadults (FX-800, $\mathrm{M}_{2}$ and FX-851, M1) and two old adults - one mature $\left(\mathrm{FX}-838, \mathrm{M}_{3}\right)$ and one senile (FX-841, $\mathrm{M}^{3}$ ).

\section{FINAL REMARKS}

The fossil remains described here show characteristics that allow the assignment to the species Notiomastodon platensis (FX-893), and to the family Gomphotheriidae (FX-800, FX838, FX-841, FX-801, FX-850, FX-851, FX-843, FX-844). The different teeth and wear stages revealed young individuals for Curití and old individuals for Mosquera. The dental and postcranial remains characterization, along with the MNI, allowed us to identify at least six individuals: two immatures (FX-801, DP ${ }_{4}$ and FX-850, DP4), two subadults (FX-800, $\mathrm{M}_{2}$ and FX-851, M1) and two old adults - one mature (FX-838, $\mathrm{M}_{3}$ ) and one senile (FX-841, $\left.\mathrm{M}^{3}\right)$. This contribution increases the knowledge about the proboscideans that lived in Center and Northeast of Colombia throughout the Quaternary period.

Future studies including geochemical and tooth enamel microwear analyses must be performed, to improve the understanding about the chronology, paleoecology, and the habitats paleoenvironment conditions from the Proboscidea during the Quaternary of Colombia.

\section{ACKNOWLEDGMENTS}

Authors thank the Geological Museum "Marino Arce Herrera" for the access to the material and to two anonymous reviewers whose comments helped to improve the manuscript. JYSI thanks CNPq for his master scholarship and CAPES for providing access to scientific papers through its website "Portal de Periódicos". LA is grateful to CAPES for the doctoral scholarship (process $\mathrm{n}^{\circ}$ 88882.443670/2019-01).

\section{REFERENCES}

Andrade, L.C.; Oliveira, E.V.; Mothé, D. \& Maniesi, V. 2020. New record of an immature Notiomastodon cf. platensis (Mammalia, Proboscidea) from Pernambuco State, Northeastern Brazil. Revista Brasileira de Paleontologia, 23:73-77. doi:10.4072/ rbp.2020.1.05

Correal-Urrego, G. 1982. Restos de megafauna asociadas a artefactos en la Sabana de Bogotá. Caldasia, 13:487-547.

Ferretti, M.P. 2008. A review of South American Proboscideans. New Mexico Museum of Natural History and Science Bulletin, 44:381-391

Ferretti, M.P. 2010. Anatomy of Haplomastodon chimborazi (Mammalia, Proboscidea) from the late Pleistocene of Ecuador and its bearing on the phylogeny and systematics of South American gomphotheres. Geodiversitas, 32:663-721. doi:10.5252/g2010n4a3

Haynes, G. 1991. Mammoths, mastodonts and elephants: biology, behavior, and the fossil record. Cambridge, Cambridge University Press, $424 \mathrm{p}$.

Lucas, S.G. 2013. The palaeobiogeography of South American gomphotheres. Journal of Palaeogeography, 2:19-40. doi:10.3724/SP.J.1261.2013.00015

Moss, C. 1996. Getting to know a population. In: K. Kangwana (ed.) Studying elephants, African Wildlife Foundation, p. 58-74.

Mothé, D. \& Avilla, L. 2015. Mythbusting evolutionary issues on South American Gomphotheriidae (Mammalia: Proboscidea). Quaternary Science Reviews, 110:23-35. doi:10.1016/j. quascirev.2014.12.013

Mothé, D.; Avilla, L.S.; Cozzuol, M. \& Winck, G.R. 2012. Taxonomic revision of the Quaternary gomphotheres (Mammalia: Proboscidea: Gomphotheriidae) from the South American lowlands. Quaternary International, 276-277:2-7. doi:10.1016/j.quaint.2011.05.018

Mothé, D.; Avilla, L.S. \& Winck, G.R. 2010. Population structure of the gomphothere Stegomastodon waringi (Mammalia: Proboscidea: Gomphotheriidae) from the Pleistocene of Brazil. Anais da Academia Brasileira de Ciências, 82:983-996. doi:10.1590/S0001-37652010005000001 
Mothé, D.; Ferretti, M.P. \& Avilla, L. 2017b. Running over the same old ground: Stegomastodon never roamed South America. Journal of Mammalian Evolution, 26:165-177. doi:10.1007/ s10914-017-9392-y

Mothé, D. et al. 2017a. Sixty years after 'The Mastodonts of Brazil': the state of the art of South American proboscideans (Proboscidea, Gomphotheriidae). Quaternary International, 443:52-64. doi:10.1016/j.quaint.2016.08.028

Osborn, H.F. 1936. Proboscidea. New York, American Museum of Natural History, $802 \mathrm{p}$.

Osborn, H.F. 1942. Proboscidea. New York, American Museum of Natural History, $960 \mathrm{p}$.

Páramo, M.A. \& Escobar, I.C. 2010. Restos mandibulares de mastodonte encontrados en cercanias de Cartagena, Colombia. Geología Colombiana, 35:50-57.

Pardo-Jaramillo, M. 2012. Reporte del hallazgo de un cráneo de Stegomastodon waringi (Holland, 1920) juvenil (Mammalia, Proboscidea) en zona rural del municipio de Turbaná, Bolívar. Colombia. Revista de la Academia Colombiana de Ciências, 36:203-210.

Paula-Couto, C. 1979. Tratado de Paleomastozoologia. Rio de Janeiro, Academia Brasileira de Ciências, 590 p.

Porta, J. 1961a. La posición estratigráfica de la fauna de mamíferos del Pleistoceno de la Sabana de Bogotá. Boletín de Geología, 7:37-54.

Porta, J. 1961b. Algunos problemas estratigráfico-faunísticos de los vertebrados en Colombia. Boletín de Geología, 7:83-104.

Porta, J. 1965. Nota preliminar sobre la fauna de vertebrados hallada en Curití (Departamento de Santander, Colombia). Boletín de Geología, 19:111-115.
Prado, J.L.; Alberdi, M.T.; Azanza, B.; Sánchez, B. \& Frassinetti, D. 2005. The Pleistocene Gomphotheriidae (Proboscidea) from South America. Quaternary International, 126:21-30. doi:10.1016/j.quaint.2004.04.012

Rodríguez-Flórez, C.D.; Rodríguez-Flórez, E.L. \& Rodríguez, C.A. 2009. Revisión de la fauna pleistocénica Gomphotheriidae en Colombia y reporte de un caso para el Valle del Cauca. Boletín científico, Centro de Museos, Museo de historia Natural, 13:78-85.

Simpson, G.G. \& Paula-Couto, C. 1957. The mastodonts of Brazil. Bulletin of the American Museum of Natural History, 112:125-190.

Tassy, P. 1996. Dental homologies and nomenclature in the Proboscidea. In: J. Shoshani \& P. Tassy (eds.) The Proboscidea. Evolution and palaeoecology of elephants and their relatives, Oxford University Press, p. 21-25.

Villarroel, C.; Bieva, J. \& Cadena, A. 1996. La fauna de mamíferos fósiles del Pleistoceno de Jútua, Municipio de Soatá (Boyacá, Colombia). Geología Colombiana, 21:81-87. doi:10.15446/gc

Villarroel, C. \& Clavijo, J. 2005. Los mamíferos fósiles y las edades de las sedimentitas continentales del Neógeno de la costa Caribe colombiana. Revista de la Academia Colombiana de Ciencias, 29:345-356.

Woodburne, M.O. 2010. The Great American Biotic Interchange: dispersals, tectonics, climate, sea level and holding pens. Journal of Mammalian Evolution, 17:245-64. doi:10.1007/ s10914-010-9144-8

Received in 25 March, 2020; accepted in 28 October, 2020. 